\title{
Assessment of Mandibular and Dental Arch Profiles in Subjects with Mandibular Third Molar Impaction
}

\author{
Asha $\mathbf{V}^{1 *}$, Kim Upadhyay ${ }^{2}$ and Sow Bhagya Lakshmi ${ }^{3}$ \\ ${ }^{1}$ Reader, Master of Dental Surgery, The Oxford Dental College - Department of Oral \\ Medicine and Radiology, India \\ ${ }^{2}$ Master of Dental Surgery, Department of Oral Medicine and Radiology, India \\ ${ }^{3}$ Senior Lecturer, Master of Dental Surgery, The Oxford Dental College - Department \\ of Oral Medicine and Radiology, India \\ *Corresponding Author: Asha V, Reader, Master of Dental Surgery, The Oxford \\ Dental College - Department of Oral Medicine and Radiology, India.
}

DOI: $10.31080 /$ ASDS.2020.04.1020
Received: December 14, 2020

Published: January 18, 2021

(C) All rights are reserved by Asha V., et al.

\begin{abstract}
Objectives: To determine the normal size of the mandible and the difference of the dental arch length and the total teeth size space that is important for prevention of mandibular third molar impaction.

Methods: 102 subjects were divided into two groups, based on the eruption of mandibular third molars. Impacted mandibular third molar (Group1) comprised of 50 subjects and the erupted (Group 2) comprised of 52 subjects. Mandibular length, width, index, total teeth size, dental arch length, dissimilarity in dental arch length and the total teeth size were assessed.

Results: There was a significant difference in the dental arch length, difference of dental arch length and total teeth size among the 2 groups in both genders. A noteworthy contrast was seen in the mandibular length $(\mathrm{P}<0.001)$, mandibular width $(\mathrm{P}<0.001)$, dental arch length ( $\mathrm{P}<0.001)$, total teeth size ( $\mathrm{P}-0.002)$, difference in dental arch and total tooth size (P-0.001) between males and females. The normal sized mandible should have a length within the range of $13.5 \mathrm{~cm}$ to $17.5 \mathrm{~cm}$ for males and $13.0 \mathrm{~cm}$ to $17.0 \mathrm{~cm}$ for females while normal dental arch-total teeth size difference range should be in the range of $0.40 \mathrm{~cm}-1.40 \mathrm{~cm}$ in males and $0.20 \mathrm{~cm}-1.20 \mathrm{~cm}$ in females for proper third molar positioning.

Conclusion: Based on the above findings, it may be justified to perform a preventive or therapeutic surgical removal of the lower third molars of the post pubertal patients whose parameters fall below these set values.
\end{abstract}

Keywords: Mandibular Third Molar; Impaction; Dental Arch Length; Mandibular Index

\section{Introduction}

Impaction occurs where there is prevention of tooth eruption to the functional site, owing to reduced space or abnormal developmental locus/site [1,2]. The most commonly impacted tooth is still the maxillary third molar accounting for 98 percent of impactions $[3,4]$. The prevalence of impacted third molar(mandibular) is $72.7 \%$ in the age range of $20-30$ years cohort [5].
Third molars usually erupt around 17-21 years with variations being 14 in Nigerians [6] and 26 in Europeans [7]. The growth of mandible after puberty indicates more of a mandibular impaction, which is higher in females [8-13].

Impacted third molars may or may not cause any pathological changes and their removal is inevitable owing to its risks like acute or chronic pericoronitis, periodontal problems and presence of a 
carious lesion on or the adjacent molar, fascial space infections, spontaneous fracture of the mandible, TMJ-symptoms associated with retained third molars, and odontogenic cysts or tumors [14]. Also, crowding of lower teeth leading to malocclusion is an common occurrence $[1,15]$.

Various factors have been proposed to play a role in determining the likelihood of impaction of mandibular third molars, including tooth angulation, depth relative to the occlusal plane, the available space for eruption, degree of root development and size of the tooth. Short length of the mandible is thought to be another etiologic factor in impaction of mandibular third molars [4].

An early assessment provides better management of the future impaction. Width and length of mandible, variations observed with dental arch perimeter and the total teeth size are the main parameters which help in diagnosing and treating the patient [16]. There are not many studies in literature regarding prediction of mandibular third molar impaction at an early age.

Therefore we aimed to define the average size of mandible and the variance of the length of the dental arch and overall tooth space, necessary for prevention of mandibular third molar impaction.

\section{Materials and Methods}

The study population comprised of 102 subjects visiting the OPD of The Oxford dental college and hospital Bangalore. It was a case-controlled randomized study and simple random sampling was done. The research proposal was reviewed and approved by the ethical committee of the Oxford Dental College and Hospital, RGUHS. Bangalore, India. Study group included both genders aged 20 years and above, with clinically erupted or impacted mandibular third molars. Excluded from the study were Subjects below 20 years of age, Subjects with one or more missing tooth, retained deciduous tooth/teeth, moderate to severe malocclusion and asymmetry of face.

Anthropometric measurements were done to record the length, width of the mandible and the difference of the dental arch length and total teeth size. Clinical oral examination was done using mouth mirror and probe to assess the position of the mandibular third molar. Failure of the tooth crown to reach the occlusal level of second molar, inclination of the tooth to the second molar and anterior ramus of the mandible were the criteria used to determine the presence of the impacted third molar. Mandibular dental arch impressions were taken using alginate and impression trays and casts were poured immediately using dental stone.

\section{Mandibular size measurement}

Marks were drawn with ball pen markers at specific landmarks on the face. The mandibular condyle was represented on the face by the midpoint of the tragus of the ear. The angle of the mandible was at the junction between the ramus and body of the mandible. The symphysis of the mandible was represented on the face by the soft tissue in the region of midpoint of the chin.

- Mandibular length (A) was the total distance from the condyle to the symphysis. The length was determined by adding the distance from the midpoint of the tragus to the soft tissue in the region of the angle of the mandible and the distance from the soft tissue in the region of the angle to that of the midpoint of the chin. Both distances were measured on the skin with flexible tape rule.

- Mandibular width (B) was the distance between the two angles of the mandible. The measurements were done directly on the subjects/patients with flexible tape rule closely adapted to displace the facial soft tissues.

- Mandibular index was calculated as the ratio of mandibular width and mandibular length.

- Dental Alveolar arch Measurement (C) The anterior-posterior distance of the arch from the midline to the retromolar pad on right side was measured on the dental cast. The anterior end of the dental arch was represented by the interdental papilla between the central incisors and the posterior end of the arch was represented by the mesial edge of the retro molar pad; the distance was determined by marking the posterior limit on a strip with a pen; and then the marked strip was removed and positioned on a ruler to determine the length of the dental alveolar arch. 
- Total Teeth Size Measurement (D) The total teeth sizes of the three anterior teeth, the two premolars and the two molars were measured on the dental cast with the two pointed sharp ends of a divider. First, the maximum mesio - distal width of the central, lateral incisors, and canine were measured, one point of the divider touching the mesial surface of the central incisor and the other point of the divider touching the distal surface of the canine, this distance between the two points of the divider were then determined. Same was done for the two premolars and the two molars, and the three values will be added to give the total teeth size.

The difference between the dental alveolar arch and the total teeth size (C-D) of the seven teeth was calculated and recorded for both the groups.

\section{Statistical analysis}

Descriptive statistics was used to determine the frequency, means, and standard deviation for each parameter for the two groups. Data were analyzed using the SPSS [Statistical Package for Social Science] version 22 [IBM Corp. SPSS, Statistics 22].

Student Unpaired t test was used to compare differences between the values obtained for the two groups, with $P$ values set at 0.05 and $95 \%$ confidence interval. Those values lesser than $\mathrm{P}<$ 0.05 were considered significant. The range values of the param- eters were determined by choosing the lowest value of the frequency distribution in the impacted mandibular $3^{\text {rd }}$ molar group and the highest value of the frequency distribution curve in the erupted group of both genders.

\section{Results}

Among 102 subjects there were 63 males (61.8\%), 39 females (38.2\%) Impacted group ( $\mathrm{n}-50$ ) had 23 males and 27 females, while erupted mandibular $3^{\text {rd }}$ molar group (n- 52) had 40 males and 12 females. Among males there was a significant difference in mandibular width (P- 0.02), dental arch length ( $\mathrm{P}<0.001)$, difference of dental arch length and total teeth size $(\mathrm{P}<0.001)$, among the 2 groups (Table 1). In females the mandibular length (P-0.01), dental arch length $(\mathrm{P}<0.001)$, difference of dental arch length and total teeth size $(\mathrm{P}<0.001)$ showed significant difference among the 2 groups (Table 2). A significant difference was seen in the mandibular length $(\mathrm{P}<0.001)$, Mandibular width $(\mathrm{P}<0.001)$, dental arch length $(\mathrm{P}<0.001)$, total teeth size $(\mathrm{P}-0.002)$, difference in dental arch and total tooth size (P-0.001) between males and females. The normal sized mandible should have a length within the range of $13.5 \mathrm{~cm}$ to $17.5 \mathrm{~cm}$ for males and $13.0 \mathrm{~cm}$ to $17.0 \mathrm{~cm}$ for females while normal dental arch-total teeth size difference range should be in the range of $0.40 \mathrm{~cm}-1.40 \mathrm{~cm}$ in males and $0.20 \mathrm{~cm}-1.20 \mathrm{~cm}$ in females to countenance the third molar suitably in the dental arch (Table 3).

\begin{tabular}{|c|c|c|c|c|c|c|c|c|c|c|c|}
\hline \multicolumn{12}{|c|}{ Comparison of mandibular Length between males and females using Student unpaired t test } \\
\hline \multirow{2}{*}{$\begin{array}{c}\text { Variable } \\
\text { (in cm) }\end{array}$} & \multirow{2}{*}{ Gender } & \multirow{2}{*}{$\mathbf{N}$} & \multirow{2}{*}{ Mean } & \multirow{2}{*}{ SD } & \multirow{2}{*}{$\begin{array}{l}\text { Std. } \\
\text { Error }\end{array}$} & \multirow{2}{*}{$\begin{array}{c}\text { Mean } \\
\text { Diff }\end{array}$} & \multicolumn{2}{|c|}{ 95\% CI of the Difference } & \multirow[t]{2}{*}{$\mathbf{T}$} & \multirow{2}{*}{ df } & \multirow{2}{*}{ P-value } \\
\hline & & & & & & & Lower & Upper & & & \\
\hline \multirow[t]{2}{*}{ Mand. Length } & Males & 63 & 16.07 & 1.05 & 0.13 & & & & & & \\
\hline & Females & 39 & 14.81 & 0.97 & 0.16 & 1.26 & 0.84 & 1.67 & 6.05 & 100.00 & $<0.001^{*}$ \\
\hline
\end{tabular}

Table 1

\begin{tabular}{|c|c|c|c|c|c|c|c|c|c|c|c|}
\hline \multicolumn{12}{|c|}{ Comparison of mandibular width between males and females using Student unpaired t test } \\
\hline \multirow{2}{*}{$\begin{array}{c}\text { Variable } \\
\text { (in } \mathrm{cm} \text { ) }\end{array}$} & \multirow{2}{*}{ Gender } & \multirow{2}{*}{$\mathbf{N}$} & \multirow{2}{*}{ Mean } & \multirow{2}{*}{ SD } & \multirow{2}{*}{$\begin{array}{l}\text { Std. } \\
\text { Error }\end{array}$} & \multirow{2}{*}{ Mean Diff } & \multicolumn{2}{|c|}{$95 \%$ CI of the Difference } & \multirow{2}{*}{$\mathbf{T}$} & \multirow{2}{*}{ df } & \multirow{2}{*}{ P-value } \\
\hline & & & & & & & Lower & Upper & & & \\
\hline \multirow{2}{*}{$\begin{array}{l}\text { Mand. } \\
\text { Width }\end{array}$} & Males & 63 & 13.87 & 1.08 & 0.14 & \multirow[t]{2}{*}{0.98} & \multirow[t]{2}{*}{0.57} & \multirow[t]{2}{*}{1.39} & \multirow[t]{2}{*}{4.78} & \multirow[t]{2}{*}{100.00} & \multirow[t]{2}{*}{$<0.001^{*}$} \\
\hline & Females & 39 & 12.88 & 0.89 & 0.14 & & & & & & \\
\hline
\end{tabular}

Table 2 


\begin{tabular}{|c|c|c|c|c|c|c|c|c|c|c|c|c|c|}
\hline \multicolumn{14}{|c|}{ Comparison of mandibular Index between males and females using Student unpaired t test } \\
\hline \multirow{2}{*}{$\begin{array}{l}\text { Variable } \\
\text { in } \mathbf{c m}\end{array}$} & \multirow{2}{*}{ Gender } & \multirow{2}{*}{$\mathbf{N}$} & \multirow{2}{*}{ Mean } & \multirow[t]{2}{*}{ SD } & \multirow{2}{*}{$\begin{array}{l}\text { Std. } \\
\text { Error }\end{array}$} & \multirow[t]{2}{*}{ Min } & \multirow{2}{*}{ Max } & \multirow{2}{*}{$\begin{array}{l}\text { Mean } \\
\text { Diff }\end{array}$} & \multicolumn{2}{|c|}{$\begin{array}{c}95 \% \text { CI of the } \\
\text { Difference }\end{array}$} & \multirow[b]{2}{*}{$\mathbf{T}$} & \multirow[b]{2}{*}{ df } & \multirow[b]{2}{*}{ P-value } \\
\hline & & & & & & & & & Lower & Upper & & & \\
\hline \multirow{2}{*}{$\begin{array}{l}\text { M a n d. } \\
\text { Index }\end{array}$} & Males & 63 & 0.86 & 0.06 & 0.01 & 0.75 & 1.06 & \multirow[t]{2}{*}{-0.01} & \multirow[t]{2}{*}{-0.03} & \multirow[t]{2}{*}{0.02} & \multirow[t]{2}{*}{-0.54} & \multirow[t]{2}{*}{100} & \multirow[t]{2}{*}{0.59} \\
\hline & Females & 39 & 0.87 & 0.05 & 0.01 & 0.76 & 1.00 & & & & & & \\
\hline
\end{tabular}

Table 3

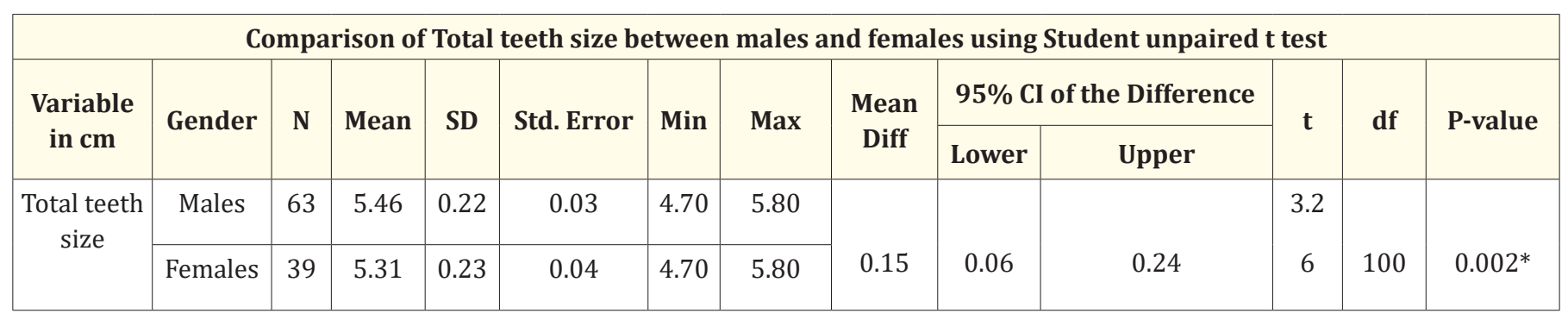

Table 4

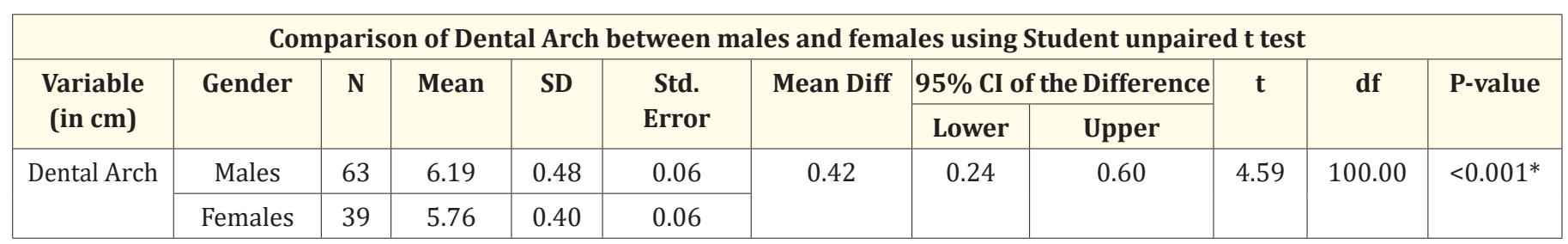

Table 5

\begin{tabular}{|c|c|c|c|}
\hline \multicolumn{2}{|c|}{ Range Values of mandibular length and difference in dental arch \& total tooth size for males and females } \\
\hline Variables (in cm) & Males & Females & P-Value \\
\hline Mand. Length & $13.5-17.5$ & $13.0-17.0$ & $<0.001^{*}$ \\
\hline Difference in dental arch and total teeth size & $0.0-1.4$ & $0.0-1.2$ & $0.001^{*}$ \\
\hline
\end{tabular}

Table 6

\section{Discussion}

Several factors have been associated with the complications associated with extraction of mandibular third molars, including age [17], health of the patient and the degree of impaction [1]. There is a significant increase in surgical morbidity as patients become older $[1,2,18,19]$.

The important causes of third molar impaction as reported in literature are hereditary factors, the tooth germ malposition, insuf- ficient third molar eruption force, tooth diameter [20,21], theory of phylogenetic regression of the jaw size - insufficient mesial movement of the dentition of modern human due to lack of interproximal attrition [22,23], insufficient development of the retro-molar space [16,20,22,24-31], short mandibular length [16,32-36] and variance in dental arch size and the overall teeth size $[13,30]$. The mandibular third molar grows in the ramus of the mandible with occlusal surface facing uphill headlong with the growing mandible providing space for the newly forming tooth along with bone re- 
sorption. The growth of the mandibular ramus is by anterior bone loss with addition at posterior surface, if this remodeling resorption at the anterior aspect of the mandibular ramus is limited, there is lack of space for the mandibular third molars to erupt $[10,20]$.

In our study, a significant difference in mandibular length between the two groups among females (P - 0.01) which is in accordance with Richardson (1977) [34] and Behbehani., et al. (2006) [22] who suggested short mandibular length predisposition mandibular third molar impaction. On the contrary among males there was no significant difference in mandibular length among the two groups (P-0.12). This is in agreement with Kaplan (1975) who found that there was no difference in mandibular length between subjects with impaction against erupted mandibular third molars. A significant difference was seen in the mandibular length between males and females (mean difference- $1.26 \mathrm{~cm}$ ) and $\mathrm{P}<0.001$, males presented with a longer mandibular length compared to females.

In the present study mandibular width also appeared to be a significant factor for eruption of mandibular third molars between two groups among males $(\mathrm{P}<0.02$.).There was a significant difference between the mandibular width of males and females (mean difference- $0.98 \mathrm{~cm}$ ) and $\mathrm{P}<0.001$. Males presented with a higher mandibular width compared to females. Mandibular index did not show any significant difference between the two groups among both males (P- 0.35) and females (P - 0.20).

Total teeth sizes had no significant difference between the impacted and erupted 3rd molar groups among both males and females. A significant difference was obtained in the total teeth size between males and females ( $\mathrm{P}-0.002)$. It can be explained as disproportionate sizes of the teeth, arch, and jaw size are also influenced by gender $[8,21]$. There was a significant difference $(\mathrm{P}<$ 0.001) in the dental arch length between the two groups in both males and females. The comparison of dental arch length between males and females also showed a significant difference (mean difference $0.42 \mathrm{~cm})$ and $(\mathrm{P}<0.001)$ Males presented with a higher dental arch length compared to females. These differences in the above parameters between males and females can be explained as males have larger and heavier jaws compared to females and also that males are found to have larger teeth than females [21].
The difference in the dental arch length and the total teeth size between the two groups was significant $(\mathrm{P}<0.001)$ in both males and females. These findings suggest that lack of space distal to the second permanent molar is an important parameter in mandibular third molar impaction, confirming with the findings of Lakhani MJ., et al. who found that a space discrepancy of $5 \mathrm{~mm}$ to $10 \mathrm{~mm}$ would present as crowding in the anterior segment and as third molar impaction in posterior segment.30 This is also in agreement with Schulhof, who stated that with a retromolar space less than $25 \mathrm{~mm}$ may cause impaction.25 Akinbami BO found that normal dental arch-total teeth size difference range should be within or above $0.71-1.20 \mathrm{~cm}$ in males and $0.76-1.10 \mathrm{~cm}$ in females to allow the third molar to position properly [8].

In our study, in dental arch length and total tooth size difference for males was 0.0 to $1.4 \mathrm{~cm}$ and that for females it was 0.0 to $1.2 \mathrm{~cm}$ which was significant (P- 0.001). These differences in the above parameters between males and females can be explained as males have larger and heavier jaws compared to females and also that males are consistently found to have larger teeth than females [21].

The above anthropological factors are invariably determined by the differential and complex effects of the interplay of both genetic and environmental influences on the pattern and direction of growth and development of the whole skull.1 This can be due to variation among different populations and ethnicities, mainly influenced by heredity, gender and evolutionary trends [21,38].

The present anthropological study on Indian population has favorably revealed that normal sized mandible should have a length within the range of $13.5 \mathrm{~cm}$ to $17.5 \mathrm{~cm}$ for males and as $13.0 \mathrm{~cm}$ to $17.0 \mathrm{~cm}$ for females while normal dental arch-total teeth size difference range should be in the range of $0.40 \mathrm{~cm}-1.40 \mathrm{~cm}$ in males and $0.20 \mathrm{~cm}-1.20 \mathrm{~cm}$ in females to allow proper positioning of the third molar

\section{Conclusion}

The two parameters showing the measurements are useful in assessing the possibility of impaction of the third molar and also the chances of post pubertal impaction. Extraction should be per- 
formed with patients' consent following explanation of the advantages of this early intervention and also the disadvantages of delay. Knowledge of the normal values of the mandibular length is also is relevant for comparison and evaluation of sizes of the mandible, in patients who need corrective orthognathic and reconstructive surgeries.

\section{Bibliography}

1. Blondeau F and Daniel NG. "Extraction of impacted mandibular third molars: postoperative complications and their risk factors". Journal of the Canadian Dental Association 73 (2007): 325.

2. Phillips C., et al. "Recovery after third-molar surgery: the effects of age and sex". American Journal of Orthodontics and Dentofacial Orthopedics 138 (2010): 700.e1-700.8 discussion 700.e1-700.8.

3. Kaya GS., et al. "Some Morphological Features Related To Mandibular Third Molar Impaction". Journal of Clinical and Experimental Dentistry 2.1 (2010): e50-55.

4. Shokri A., et al. "Position of impacted mandibular third molar in different skeletal facial types: First radiographic evaluation in a group of Iranian patients". Imaging Science in Dentistry 44 (2014): 61-65.

5. Odusanya SA and Abayomi I0. "Third molar eruption among rural Nigerians". Oral Surgery, Oral Medicine, Oral Pathology 71.2 (1991): 151-154.

6. Kruger E., et al. "Third molar outcomes from age 18 to 26: findings from a population-based New Zealand longitudinal study". Oral Surgery, Oral Medicine, Oral Pathology, and Oral Radiology 92.2 (2001): 150-155.

7. Bishara S and Andreasen G. "Third molars a review". American Journal of Orthodontics 1 (1983): 83.

8. Olayemi AB. "Assessment and determination of human mandibular and dental arch profiles in subjects with lower third molar impaction in Port Harcourt, Nigeria”. Annals of Maxillofacial Surgery 1.2 (2011): 126-130.
9. Hugoson A and Kugelberg CF. "The prevalence of third molars in a Swedish population. An epidemiological study". Community Dental Health 5 (1988): 121-138.

10. Akinbami BO and Didia BC. "Analysis of body variables, mandible and dental arch variables in the prediction of lower third molar impaction". Journal of Community Dental Practice 11 (2010): 1-10.

11. Berge TI. "Inability to work after surgical removal of mandibular third molars". Acta Odontologica Scandinavica 55 (1997): 64-69.

12. Chiapasco M., et al. "Side effects and complications associated with third molar surgery". Oral Surgery, Oral Medicine, Oral Pathology 76.4 (1993): 412-420.

13. Juodzbalys G and Daugela P. "Mandibular Third Molar Impaction: Review of Literature and a Proposal of a Classification". Journal of Oral and Maxillofacial Surgery 4 (2013).

14. Chiapasco M., et al. "Side effects and complications associated with third molar surgery". Oral Surgery, Oral Medicine, Oral Pathology 76.4 (1993): 412-420.

15. Koerner KR. "The removal of impacted third molars. Principles and procedures". Dental Clinics of North America 38.2 (1994): 255-278.

16. Lilian H Karasawa., et al. "Cross-sectional study of correlation between mandibular incisor crowding and third molars in young Brazilians". Medicina Oral, Patologia Oral y Cirugia Bucal 18.3 (2013): e505-e509.

17. Bruce RA., et al. "Age of patients and morbidity associated with mandibular third molar surgery". Journal of the American Dental Association 101.2 (1980): 240-245.

18. National Institute of Health. "NIH consensus development conference for removal of third molars". Journal of Oral Surgery 38 (1980): 235-236.

19. Richardson ME. "Some Aspects Of Lower 3RD molar eruption". Angle Orthodontist 44.2 (1974). 
20. Ganss C., et al. "Prognosis of third molar eruption". Oral Surgery, Oral Medicine, Oral Pathology 76 (1993): 688-693.

21. Bergström $\mathrm{K}$ and Jensen R. "Responsibility of the third molar for secondary crowding". Dental Abstract 6 (1961): 544.

22. Lytle JJ. "Etiology and indications for the management of impacted teeth". Northwest Dentistry 74.6 (1995): 23-32.

23. Lakhani M J., et al. "Anterior Arch Crowding -A Possible Predictor For Mandibular Third Molar Impaction". Journal of Ayub Medical College Abbottabad 23.1 (2011).

24. Schulhof RJ. "Third molars and orthodontic diagnosis". Journal of Clinical Orthodontics 10 (1976): 272-281.

25. Behbehani F., et al. "Prediction of mandibular third-molar impaction in adolescent orthodontic patients". American Journal of Orthodontics and Dentofacial Orthopedics 130 (2006): 4755 .

26. Hattab F N., et al. "Radiographic evaluation of mandibular third molar eruption space". Oral Surgery, Oral Medicine, Oral Pathology 88 (1999): 285-291.

27. Lindqvist B and Thilander B. "Extraction of third molars in cases of anticipated crowding in the lower jaw". American Journal of Orthodontics 81 (1982): 130-139.

28. Forsberg CM. "Tooth size, spacing, and crowding in relation to eruption or impaction of third molars". American Journal of Orthodontics and Dentofacial Orthopedics 94 (1988): 57-62.

29. Ricketts RM., et al. "Third molar enucleation: diagnosis and technique". Journal of the California Dental Association 4 (1976): 52-57.

30. Zeli K and Nedeljkovi N. "Size of the lower third molar space in relation to age in Serbian population". Vojnosanitetski pregled 70.10 (2013): 923-928.

31. Bugaighis I., et al. "An odontometric study of tooth size in normal, crowded and spaced dentitions". Journal of Orthodontic Science 2 (2013): 95-100.
32. Björk A., et al. "Mandibular growth and third molar impaction". Acta Odontologica Scandinavica 14 (1956): 231-272.

33. Bjork A. "Variations in the growth pattern of the human mandible: longitudinal radiographic study by the implant method". Journal of Dental Research 42 (1963): 400-411.

34. Capelli J. "Mandibular growth and third molar impaction in extraction cases". Angle Orthodontist 61 (1991): 223-229.

35. Hassan AH. "Cephalometric characteristics of Class II division 1 malocclusion in a Saudi population living in the western region". Saudi Dental Journal 23 (2011): 23-27.

36. Kaplan RG. "Some factors related to mandibular third molar impaction". Angle Orthodontist 45 (1975): 153-158.

37. Almpani $\mathrm{K}$ and Kolokitha $\mathrm{O}$ E. "Role of third molars in orthodontics”. World Journal of Clinical Cases 3.2 (2015): 132-140.

\section{Assets from publication with us}

- Prompt Acknowledgement after receiving the article

- Thorough Double blinded peer review

- Rapid Publication

- Issue of Publication Certificate

- High visibility of your Published work

Website: www.actascientific.com/

Submit Article: www.actascientific.com/submission.php Email us: editor@actascientific.com

Contact us: +919182824667 